\title{
The Daily Life and Reality Behind Child Poverty in Sweden: Children's and Adolescents' Voices
}

\author{
Ylva Odenbring ${ }^{1}$ (D)
}

Accepted: 6 May 2018 / Published online: 16 May 2018

(C) The Author(s) 2018

\begin{abstract}
Today, approximately 12\% of children growing up in Sweden are living in what could be defined as child poverty. Although the number of children living in poverty has slightly decreased during recent years, social exclusion and segregation between different groups in society have increased. The present study will shed a light on the reality of how children and adolescents living in poverty experience their daily lives. Analytically, the study explores how these experiences connect to different practices concerning child poverty. The study draws from an empirical and theoretical analysis of interviews with children and adolescents published in the Swedish Save the

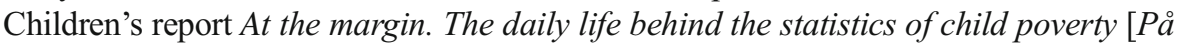
marginalen. Vardagen bakom barnfattigdomsstatistiken]. The results reveal that lack of material and financial resources creates social stigmatization for this group of children and adolescents; they have fewer possibilities to spend time with peers, and this quite often also results in self-exclusion. The children's and adolescents' narratives also indicate the importance of the social role of the school, here in relation to the school providing nutritious school lunches and free packed lunch for school excursions.
\end{abstract}

Keywords Adolescents $\cdot$ Children $\cdot$ Child poverty $\cdot$ Daily life $\cdot$ School $\cdot$ Social injustice . Stigmatization

\section{Introduction and Aim}

Boy aged 13: I think you should drop the idea that Sweden is a rich country, because then all children in Sweden would be "rich", but that is not the case you know, because there are quite a lot of children who are living in poverty (Save the Children 2013, p. 18).

Ylva Odenbring

ylva.odenbring@gu.se

1 Department of Education Communication and Learning, University of Gothenburg,

Läroverksgatan 15, 40530 Gothenburg, Sweden 
This introductory quote has been chosen for its representation of Swedish children growing up in poverty. Contemporary research shows that children's living conditions look very different owing their family's financial situation (Beach and Sernhede 2011; Bunar and Sernhede 2013; Lundberg 2015; Öhrn 2012). In Sweden, the number of children and adolescents living in child poverty is highest in the greater metropolitan areas of Malmö, Gothenburg and Stockholm (Sernhede 2011; Save the Children 2014). A majority of these children are growing up in the so-called Million Homes Programme areas [Miljonprogramsområden]: suburbs that have become socially stigmatized neighbourhoods (Beach and Sernhede 2012). The Million Homes Programme was implemented during the period 1965-1974 and was intended to provide one million new homes. Today these neighbourhoods provide homes for approximately $20 \%$ of the population in Sweden. These neighbourhoods have become the most socially disadvantaged areas in the country and are characterized by a high proportion of people living on social welfare and families living in overcrowded apartments (Odenbring et al. 2018; Sernhede 2011).

The research shows that growing up in child poverty entails several levels of stigmatization and social injustice (Akande 2000; Heymann 2000; Horst and Pihl 2010; Sernhede 2011; Wacquant 2008) Children growing up in society's margin have an increased risk of poor physical and mental health, lower academic achievement compared to other students, increased risk of school drop-out, lower educational level and fewer opportunities for employment in their future lives. These issues should not be understood as separate issues or problems, because they quite often overlap. Previous studies have also indicated that there are quite often strong societal moralizations concerning adults and children living in poverty, i.e. these people are considered and categorized as lazy and they are assumed to be to blame for their current situation (Näsman 2012). As a result, they are at greater risk of being excluded from the rest of the society and stigmatized. However, if we take a closer look at the research field on child poverty, we find it has mainly included quantitative studies on the effects of growing up during economic hardship and poverty and the scale of it. It is with this background the current study aims to investigate how children and adolescents growing up in child poverty experience and describe their daily lives. The following research questions have guided the investigation:

1) How do the children and adolescents experience their daily lives?

2) What challenges do the children and adolescents say they have to face at school and during their free time?

3) What kinds of support do the children and adolescents report are vital to helping them?

\section{Child Poverty in Sweden}

From a broader international perspective, children's living conditions in Sweden are better compared to those in most countries, but this does not mean there are no children in Sweden living under economic hardship and child poverty (UNICEF 2012). When comparing children's living conditions in the Nordic countries (i.e., Denmark, Finland, Iceland, Norway and Sweden), approximately $12 \%$ of children in Sweden are living in poverty, which is the highest percentage of child poverty in the Nordic countries (Save 
the Children 2014; UNICEF 2012). And despite the fact that the number of children living in poverty during recent years has slightly decreased in Sweden, the tendency over the past decades indicates that social exclusion and segregation between different groups in the society have increased. The largest social exclusion and differences are to be found in neighbourhoods in the greater metropolitan areas (Save the Children 2014). The city of Malmö in the county of Skåne, in Southern Sweden, has the highest proportion of children living in poverty in the country. Approximately $32 \%$ of children in Malmö are living in child poverty. In the city of Malmö, there are neighbourhoods in which $50 \%$ of the children are living in poverty. The proportion of children growing up in child poverty is highest among children living with single parents (mum) and/or parents with an immigrant background.

There are different ways of measuring poverty, but regardless of the measurement system, incomes at a certain minimum level are used to define poverty. In Sweden, the most commonly used measurement systems are: 1) EU poor: the family's income is at the highest $60 \%$ of the country's median level; 2) low standard of living: this is based on the disposable family income after tax and basic consumption and housing and 3) low standard of living: lacking of material resources (Save the Children 2002; 2013; 2014).

From an international perspective, all children should be ensured an adequate standard of living. In Article 27 of the Convention on the Rights of the Child (1990), several aspects connected to children's right to an adequate standard of living, housing, nutrition, wellbeing and mental health and support are stipulated:

1. States Parties recognize the right of every child to a standard of living adequate for the child's physical, mental, spiritual, moral and social development.

2. The parent(s) or others responsible for the child have the primary responsibility to secure, within their abilities and financial capacities, the conditions of living necessary for the child's development.

3. States Parties, in accordance with national conditions and within their means, shall take appropriate measures to assist parents and others responsible for the child to implement this right and shall in case of need provide material assistance and support programmes, particularly with regard to nutrition, clothing and housing (Convention on the Rights of the Child 1990, p.8).

\section{Survey of the Field}

Children's possibilities to participate in spare time activities depend on the family's financial situation, and in the long term lack of possibilities may lead to health-related problems. Research has shown that children who cannot afford to participate in freetime activities also have fewer opportunities to create social relations to other children (Harju 2013; Näsman 2012). Limited financial resources also entail, for example, difficulties in buying new clothes. Research has shown that children with low material standards often experience social stigmatization and are teased and exposed to bullying at school (Fernqvist 2012; Harju and Thorød 2011). Additionally, there is research indicating that children, despite their disadvantaged situation, try to create a meaningful free time. These children also express their desire to create a better life and future not only for themselves, but also for their family (Roets et al. 2015). 
The research literature on children growing up in child poverty has revealed that these children have to find strategies to prepare their parents for unexpected expenses for example, food to take on school excursions - so the family can make economic plans for this (Fernqvist 2012). In families with financial difficulties, long-term planning is often required to cover the most fundamental things (Harju 2013; Näsman 2012). Children growing up in poverty are very often aware of their difficult situation and are often forced to assume great responsibility for the family's financial situation. For instance, some children must use their own pocket money to buy fruit and food for school excursions (Harju 2013; Harju and Thorød 2011).

The research literature has also shown that children living in poverty have fewer opportunities to get help and support with their homework. This is because the parents of this group of children often face different barriers to helping their children with homework (Heymann 2000). The barriers are often related to parents' low educational level, and for (low-income) working parents, extended working hours also prevent them from assisting their children. Studies have indicated that children who must care for themselves have poorer school outcomes and academic achievement compared to other groups of children, but they are also at greater risk of being exposed to violence, crime as well as of using drugs and alcohol (Heymann 2000; Tuason et al. 2009).

Researchers have encouraged policymakers to provide children after-school programmes or after-school care services than can support vulnerable children. It has also been recognized that children and youth from low-income families, in particular, will benefit from such programmes. Not only do after-school programmes provide a safe and secure environment for this group of vulnerable children, they also have a positive impact on the children's wellbeing, academic achievement and social relations with other children (Heymann 2000; Tuason et al. 2009). Another form of prevention work that has been recognized in previous research is affordable housing (Deck 2017). Affordable housing creates a stable home environment for the children, which has a positive impact on their wellbeing, school attendance and academic achievement.

The above research overview shows some tendencies in the field. It is hoped that the present study will generate new knowledge about the reality and hardship of children and adolescents growing up in society's margin and about what support systems they feel are necessary to creating a better life.

\section{The Study}

Since 2002, Swedish Save the Children has published annual reports on the changes in children's welfare in Sweden. These reports are based on figures and statistics on child poverty in the country, with one exception, and that is the report entitled At the margin. The daily life behind the statistics of child poverty [På marginalen. Vardagen bakom barnfattigdomsstatistiken] (Save the Children 2013). This is the only report to date about the daily lives behind and the voices of child poverty published by Save the Children. The data published in the report are based on twelve deep interviews with children aged 7-18 years and a hearing with a group of children. All participants were contacted through Save the Children or through external organizations and were asked whether they wanted to participate and share their experiences of living and growing up under circumstances of economic hardship. 
Given this background, the point of departure of the present study is to empirically and theoretically analyse the data published in this particular report. More specifically, the aim of the study is to explore how the daily lives of children and adolescents living in poverty connect to different experiences and practices concerning living conditions in the society's margin. The interviews analysed and presented in the current study were conducted with children and adolescents 9-16 years of age, which means that all children were attending compulsory schooling at the time of the interviews.

\subsection{Theoretical Framework and Data Analysis}

Theoretically, the present study is influenced by Bourdieu's (1998) and Skeggs's (2002) work. Bourdieu (1998) uses different forms of capital to explain and understand the mechanisms of social positions or social class in society. This model of social positions is based on the assumption that various forms of capital create different possibilities to navigate through social space. Possession of these forms of capital can be abstract or material in nature. Bourdieu $(1997,1998)$ talks about and defines four forms of capital: economic capital: which includes money and monetary assets and may also result in property rights; cultural capital: which includes educational level and lifestyle; social capital: which includes social networks. Bourdieu also talks about symbolic capital, which includes any form of capital and is the outcome of existing social divisions in society such as rich/poor, cultured/uncultured or strong/weak. Symbolic capital concerns how specific persons or physical possessions are given certain recognition or value.

The present article will primarily draw on Bourdieu's (1998) notion of economic capital. In the study, economic capital provides an analytical tool for analysing how children and adolescents refer to the family's financial situation and lifestyle and how this impacts their lives on a daily basis. This concern, for instance, being able to take part in certain activities, as pursuing a certain lifestyle requires having a certain economic position. Skeggs's (2002) work has also provided a useful analytic tool in the current study. Bourdieu's forms of capital have been an inspiration in Skeggs's work. According to Skeggs, these forms of capital enable us to see and understand how class operate on the concrete level of everyday life as well as on the societal structural level. For example, using the economic capital provides a useful tool in understanding how resources and access contribute to class formations and social injustice, and the mechanisms underlying them. As Skeggs agues: "Each kind of capital can only exist in the interrelationships of social positions; they bring with them access to or limitation on which capitals are available to certain positions" (Skeggs 2002, p. 9). In the present study, the concept of social injustice will be used to refer of processes of social positions (i.e. class formations) of how social injustice is constructed and reproduced on a daily basis in society. Together, Bourdieu's and Skeggs's work have provided a useful theoretical framework for understanding and thematically analysing how children and adolescents growing up in conditions of economic hardship describe and experience their daily lives.

\subsection{Thematic Analysis}

The data have been thematically analysed, which means I have read through the interview extracts carefully multiple times to identify recurrent patterns in the 
narratives. This form of analysis provides a flexible approach and it is a useful method for examining and highlighting similarities and differences in a data set. It is also useful for summarizing key features in the data (Nowell et al. 2017). Braun and Clarke (2006) developed six analytical phases, or steps, that they claim are central when using thematic analysis as a methodological tool (see also Nowell et al. 2017). The present study is inspired by this work, but the six steps have been slightly modified to better fit the aim and design of the present study. These steps (or phases) were as follows: 1) becoming familiar with the data, 2) initial coding of the data, 3) searching for recurrent patterns in the data, i.e. themes, 4) reviewing the main themes and sub-themes, 5) defining and naming the themes and, finally, 6) writing and finalizing the paper. During the analysis of the data, two broad themes emerged in the analysis. The empirical data and the results will be organized according to these two separate themes: 1) School lunches and excursions and 2) Free-time activities.

\section{School Lunches and Excursions}

Sweden has a long tradition of working with social justice in education and creating an equal educational system for all children. One cornerstone is costs. Students in Sweden do not have to pay tuition fees in the lower, secondary and upper secondary school levels and textbooks and other school material are free of charge (SFS 2010:800). All schools in Sweden are also required to serve free school lunches, making Sweden together with Finland the only countries in the world where students are served free school lunches (Odenbring 2014; SFS 2010:800). The political intention behind free school lunches is based on the understanding that hungry children will not grow and develop into healthy individuals and that hungry children will also have difficulty managing their schoolwork. Since the mid-1970s, it has been compulsory for schools in Sweden to serve free school lunches. Still, free school lunches are particularly important for the most vulnerable students, as pointed out by one teenage boy in the interview material.

Boy, aged 11: If you're poor you don't get good food at home, that is why it's extra important to get nutritious meals at school! (Save the Children 2013, p. 37)

There is research showing that the school has an important social role to play in serving school lunches (Näsman and Greber 1996). Statistically, the schools serve more meals on Mondays and this is because there are children who come to school with empty stomachs after the weekend. Many school kitchen managers are aware of this and prepare extra meals not only on Mondays, but also on Fridays before the children leave the school for the weekend (Majblomman 2017). The importance of providing meals for children at school has also been stressed in research outside the Nordic context. American research, for example, has shown that poor children benefit from food programmes, because such programmes have positive outcomes in relation to children's health status as well as academic achievement (Ashiabi 2005; Rodgers and Milewska 2007).

The narratives that are framed on the basis of the importance of nutritious meals connect to the social role of the school. The social role of the school also includes the importance of the support that individual teachers and other school officials offer students, as suggested by one teenage girl. 
Girl aged 16: Sometimes we don't have breakfast at home and I'm hungry at school. I'm so hungry that I can't think. I usually lie about it and tell the teachers that I didn't have time for breakfast and ask the teacher for a fruit. Sometimes I go to the school nurse and sit there and talk during a whole class, because then I can get a fruit. Sure, I miss a class, but that's better than being hungry. Now they've started to serve breakfast at school (Save the Children 2013, p. 37).

Another dimension that emerged in the data is related to school excursions. Although it is stated in the Education Act that education should be free, schools are allowed to organize school activities, such as school excursions and trips, that might result in negligible costs for the students (SFS 2010:800). Yet these expenses should be voluntary for guardians and such activities should also be available to all students. However, the definition of voluntary when it comes to school excursions is questionable, as school excursions are connected to a social pressure to participate. Among the children in the data, the topic of school excursions is connected to several difficulties.

Girl, aged 12: There are quite a lot who are poor! There are those who can't afford clothes, activities, food and shoes. And there are those who are hungry, even. Some kids don't have food at home and sometimes when you have to bring a packed lunch [to school excursions] you don't get any food. My friend always brings me a hamburger (Save the Children 2013, p. 18).

In this regard, the children and adolescents report that support from teachers and school officials is crucial, but they also bring up the importance of friendly classmates who reach out a helping hand. Previous research has shown similar results. Children growing up in child poverty experience great pressure when they are forced to bring a packed lunch or fruit to school excursions (Harju and Thorød 2011). Quite often these children come to school empty handed because their parents are unable to provide them with the extra fruit or lunch from home. For students living in poverty, the schools' organization and how the school financially organizes excursions and trips are crucial.

Girl aged 16: When the school pays for school trips, excursions and food, and particularly when they bring extra food so you get really full, then it doesn't cost as much for me (Save the Children, p. 16).

Boy aged 15: Once when I didn't have rubber boots and money for a school trip I called my contact person at the Social Services, so she helped me out. The school is better today than it was before, because they pay for the bus ticket so everyone can join in. There are also nice people who share their packed lunches during school excursions (Save the Children 2013, p. 32).

The social role of the school also frames the narratives about school excursions, although other agencies in society, such as the Social Services, also play an important role here. In the children's narratives, charity organizations are also mentioned as vital when it comes to schools' possibilities to support the most vulnerable students and cover the extra expenses associated with school excursions. 
Girl aged 12: Quite often the school pays for the excursions. We collect money by selling home baked buns and sell Mayflower pins and stickers [the charity organization Majblomman] (Save the Children 2013, p. 39).

The girl in the excerpt above referred to Majblomman, Sweden's oldest charity organization. Majblomman aims at financially supporting children growing up in poverty. In April, every year school children all around the country sell pins and stickers to support Majblomman's work. Overall, the general trend in Swedish society is towards the increased importance of charity organizations. Contemporary research indicates that when society fails to provide the necessary support for the most vulnerable groups, charity organizations, such as Majblomman, become a more important part of the welfare system (Odenbring et al. 2016).

\section{Free-Time Activities}

Growing up in conditions of economic hardship and child poverty also creates limited opportunities to take part in different free-time activities, such as sports activities or simply hanging out with friends. In the long run, this could increase the risk of social exclusion and have an impact on social relations with other children (Harju 2013; Näsman 2012). Children's experiences of not having money not only create a stigma, because it is sensitive to talk about this issue, but also limit opportunities to form trustful relations with other people.

Girl, aged 12: It's very sensitive to talk about money. It could be super embarrassing and you might be bullied and harassed and things like that. It is not something I walk around and tell people, that I don't have money. Because it's hard to trust most people (Save the Children 2013, p. 24).

Creating trust is one of the important issues mentioned in the children's narratives. Shame is another dimension that emerged. Not being able to afford the same things as your classmates and being forced to skip activities lead to stress and anxiety. The children's narratives about their daily lives and free-time activities are framed on the basis of their experiences of stigmatization.

Girl, aged 15: There are actually levels of poverty. How easy do you think it is to sit in a classroom with your classmates who make different plans for the weekend and then you know you cannot afford these things? You are worried that your sneakers might fall apart by the end of the month because you've been wearing them forever. Sometimes you have to skip activities at school because you can't pay for the extra expenses. At the same time, you constantly hear that there are no poor people in Sweden. Then you feel stupid and have to tell yourself that there are poorer people in the world (Save the Children 2013, p. 19).

Similar to the narrative of the girl above, another girl in the data also expresses her frustration with the stigma attached to child poverty.

Girl, aged 16: Take a look how we live, ask questions to me and my mum about how much money we have, join us to the grocery store when we have to buy 
groceries. And most of all take a look what we do with our money when we actually have some (Save the Children, 2013, p. 17).

The children in the study did not only report that poverty creates a stigma, but they also believed there was little general knowledge in society about this issue and about what poverty actually means of the daily lives of poor families. For this group of children, the financial situation also limits their ability to socialize with their friends during their free time. One of the things the children expressed concerns bringing home friends after school. Owing to the family's lack of material resources, these children often avoid bringing friends to their homes.

Boy, aged 9: I would never bring home friends, because it's so embarrassing that we have so few things compared to others (Save the Children 2013, p. 25).

As suggested in a previous study, this group of children also experience other limitations and difficulties associated with bringing their friends home after school. Because of the family's financial situation, the family cannot afford to serve extra meals, such as an extra afternoon snack when the children have their friends over. This is why this group of children quite often avoid bringing their friends home after school (Fernqvist 2012).

The feeling of stigmatization also occurs in the narratives about the school breaks, such as the summer holidays. Holidays are often a difficult time for this group of children. While children with better economic circumstances have opportunities to travel, visit new places, participate in summer camps or meet new friends, poor children are often forced to stay at home, do home activities and find their own ways of making the best of holiday periods. As a result, this group of children has to find strategies for dealing with questions about summer holiday activities. Self-exclusion is a common strategy for dealing with the matter, but a strategy that should be understood as involuntary.

Girl, aged 16: My friends go to outdoor pools during the summer, it's super cosy. But I can't join them because I have no money. My friends offer to pay for the trip for me, but I have no swimwear. I can't buy a bikini, because it will be too expensive. They say that I can call them when I want to join them, but it will take at least a hundred years before I can buy swimwear. So, I stay at home instead (Save the Children 2013, p. 26).

There are also cases when children have the courage to tell their friends about the family's difficult financial situation. One of the boys interviewed mentioned that it is easier to handle these issues now that he is a teenager.

Boy, aged 15: I've had the feeling several times when everyone else has been to Paris or America, that I wished I could go. When you're younger it's hard to tell everyone that you haven't done anything during the holidays, but now that I'm older, I can say that we can't afford this right now (Save the Children 2013, p. 29).

Despite the anxiety connected to the difficult financial situation, this group of children also expressed a great awareness about the free activities offered to children and adolescents who cannot afford various activities during the school beaks. 
Boy, aged 13: Those who have a lot of money travel, and those who don't stay at home. There should be an open leisure centre in every suburb and neighbourhood that arranges activities and cheap trips for the kids who have to stay at home (Save the Children 2013, p. 29).

In the extract above, open leisure centres are mentioned as an important societal institution to support poor children during their free time. The open leisure centres are public youth clubs open to all young people who want to participate in different leisure activities or just hang out with other adolescents (Lindström 2016). It is the local councils that run the open leisure centres and most of the activities at the centres are free of charge. Although research has recognized that vulnerable youth benefit from open leisure-time centre activities, the number of such centres has decreased in Sweden since the economic crisis in the 1990s.

\section{Conclusion}

The present study has investigated how children and adolescents living in economic hardship experience their daily lives, what challenges they say they have to face and what kind of support they find vital to helping them in their difficult situation. The present study's theoretical framework draws from Bourdieu's (1998) and Skeggs's (2002, 2004) work and understanding of social positions. According to Skeggs (2002), Bourdieu's forms of capital enable us to see and understand how social positions (social class) operate on the concrete, everyday life level as well as on the societal structural level. In the study, the concept of economic capital has provided a useful tool for analysing and understanding how social injustice frames the daily lives of children and adolescents living in poverty.

The lack of financial resources mentioned by the children and adolescents in the current study shows how social injustice is produced through everyday practice at school as well as during their free time. One of the recurrent patterns framing the children's and adolescents' narratives was connected to the strategies they have to use to navigate through social space (cf. Skeggs 2004). The children and adolescents reported that lack of material and financial resources, i.e. economic capital (Bourdieu 1998), has a great impact on their possibilities to build social relations with peers. On the concrete level, this meant that they avoided bringing friends home after school or participating in various free-time activities. The lack of economic capital has symbolic effects that result in marginalization and a stigmatized position for these children and adolescents. Bourdieu (1998) talks about and defines similar effects in terms of symbolic violence, i.e. a form of violence on a symbolic and structural level, that excludes certain groups from collective opportunities. The stigmatization that the children and adolescents in the present study reported is, I believe, equivalent to processes of symbolic violence.

The other identified recurrent theme in the empirical analysis connects to the social role of the school. On a concrete level, this included providing nutritious school lunches and free packed lunches for school excursions (cf. Skeggs 2002). For the children and adolescents growing up in circumstances of economic hardship, this kind of compensatory system makes a great difference on a daily basis. Awareness among the school 
professionals is another dimension of the school's social role that emerged in the empirical analysis. The children and adolescents reported that when school professionals recognize as well as act on and deal with these issues, the school can actually offer them the support they need.

As suggested in previous research, poverty is often connected to feelings of shame for the entire family (Harju 2013). Shame is not only tied to lack of material resources, as shown in the current study, but many families also find it shameful to ask the social services for help and support (Näsman 2012). In light of the present results, having both a professional collaboration between home and school and a well-functioning collaboration between the school and social services supporting these families is crucial.

\section{Discussion}

Despite increased segregation in Sweden, research on children's experiences of living in conditions of economic hardship and child poverty is still a little explored field (Näsman 2012). Previous Swedish as well as international research has mainly involved quantitative studies discussing this issue in terms of the scale of the problem and the long-term side effects of it. The present study has generated new knowledge about children's and adolescents' experiences of daily life in child poverty.

Taking a children's rights perspective and looking at this at the individual child will benefit from a well-functioning social support system, as such a system will improve his/her mental health and wellbeing. As show in the current study, one key factor is that school professionals be aware of students' home situation and find concrete ways of supporting students. Contemporary Swedish research shows that a well-functioning student welfare team is crucial in these situations. As a way of creating a compensatory support system for students living in economic hardship, student welfare teams at some Swedish schools located in socially disadvantaged areas have decided to serve breakfast before the school day starts (Odenbring et al. 2017). Decisions of this kind are based on the knowledge that a good start of the day and a nutritious breakfast will create a situation in which more students will be able to improve their school work and academic achievement. Looking at it from a wider perspective, Swedish society as a whole will also benefit. With increased health rates, more children will manage school, and in the long run this will create possibilities for more young people to enter the labour market, thus securing their future financial situation.

Although moralizations about poverty were not identified in the empirical data analysed here, they are nonetheless important to discuss in relation to child poverty. On the societal level, poverty is often connected to a moral value system and moralizations about families living in poverty. This form of moral system and judgement constructs notions of immorality where families are blamed for their situation and lifestyle (Odenbring at al. 2016) . As Skeggs (2004) puts it: "The powerless are positioned by the symbolic evaluation of immorality, whilst the powerful claim morality for themselves" (p. 95). This raises questions not only about how issues of child poverty could be critically discussed on a general societal level, but also about how to provide the necessary education and tools for professionals working with children and adolescents on a daily basis. Last, but not least, more research based on interviews as well as ethnographic research conducted in, for instance, 
preschools and schools - exploring children's experiences and the reality of living in economic hardship - will be necessary and should also be encouraged and financially supported in the future.

Open Access This article is distributed under the terms of the Creative Commons Attribution 4.0 International License (http://creativecommons.org/licenses/by/4.0/), which permits unrestricted use, distribution, and reproduction in any medium, provided you give appropriate credit to the original author(s) and the source, provide a link to the Creative Commons license, and indicate if changes were made.

\section{References}

Akande, A. (2000). Effect of exposure to violence and poverty on young children: the southern African context. Early Child Development and Care, 163, 61-78.

Ashiabi, G. (2005). Household food insecurity and children's school engagement. Journal of Children and Poverty, 11(1), 3-17.

Beach, D., \& Sernhede, O. (2011). From learning to labor to learning for marginality. British Journal for Sociology of Education, 32(2), 257-274.

Beach, D., \& Sernhede, O. (2012). Learning processes and social mobilization in a Swedish metropolitan hiphop collective. Urban Education, 47(5), 939-958.

Bourdieu, P. (1997). The forms of capital. In A. H. Halsey, H. Lauder, P. Brown, \& S. Stuart Wells (Eds.), Education, culture, economy, society (pp. 46-58). Oxford: Oxford University Press.

Bourdieu, P. (1998). Practical reason. On the theory of action. Cambridge: Polity Press.

Braun, V., \& Clarke, V. (2006). Using thematic analysis in psychology. Qualitative Research in Psychology, 3, $77-101$.

Bunar, N., \& Sernhede, O. (Eds.). (2013). Skolan och ojämlikhetens urbana geografi. Om skolan, staden och valfriheten. Göteborg: Daidalos.

Convention on the Rights of the Child (1990). Retrieved October 23 ${ }^{\text {rd }}$, 2017, from: http://www.ohchr. org/Documents/ProfessionalInterest/crc.pdf

Deck, S. M. (2017). School outcomes for homeless children: differences among sheltered, doubled up, and poor, housed children. Journal of Children \& Poverty, 23(1), 57-77.

Fernqvist, S. (2012). Barns strategier och ekonomisk utsatthet - knappa resurser som utgångspunkt för en förhandling av positionerna i familjen. Sociologisk Forskning, 49(3), 173-188.

Harju, A. (2013). Skola och föräldrar med knapp ekonomi. In A. Harju \& I. Tallberg Broman (Eds.), Föräldrar, förskola och skola. Om mångfald, makt och möjligheter [Parents, preschool and school. Diversity, power and possibilities] (pp. 107-120). Lund: Studentlitteratur.

Harju, A., \& Thorød, A. B. (2011). Child poverty in a Scandinavian welfare context - From children's point of view. Child Indicators Research, 4(2), 283-299.

Heymann, J. (2000). What happens during and after school: Conditions faced by working parents living in poverty and their school aged children. Journal of Children \& Poverty, 6(1), 5-20.

Horst, C., \& Pihl, J. (2010). Comparative perspectives on education in the multicultural Nordic countries. Intercultural Education, 21(2), 99-105.

Lindström, L. (2016). The case of open leisure activities organized in Swedish local councils: The role of citizenship and entrepreneurship skills development. Citizen, Social and Economics Education, 15(2), $104-116$.

Lundberg, O. (2015). Mind the gap: Ethnography about cultural reproduction of difference and disadvantage in urban education. Göteborg: Acta Universitatis Gothenburgensis.

Majblomman. (2017). Barns sommarlov och kommuners bristande ansvar. Majblommans årliga sommarlovsrapport om barns belägenhet $i$ svenska kommuner när skolan stänger [Children's summer holidays and municipalities' lack of responsibility. Majblomman's annual summer holiday report about children's situation in Swedish municipalities when school is closed]. Rapport no. 37. Retrieved October 23 ${ }^{\text {rd }}$, 2017, From: http://www.majblomman.se/Global/Rapporter/Sommarlov/Sommarlovsrapport\%202017. pdf.

Nowell, L. S., Norris, J. M., White, D. E., \& Moules, N. J. (2017). Thematic analysis: Striving to meet the trustworthiness criteria. International Journal of Qualitative Methods, 16, 1-13. 
Näsman, E. (2012). Barnfattigdom - om bemötande och metoder ur ett barnperspektiv [child poverty Approach and methods from a child perspective]. Stockholm: Gothia Förlag.

Näsman, E. \& von Greber C. (1996). Mamma, pappa utan jobb [mum, dad without employment]. Stockholm: Rädda Barnens Förlag.

Odenbring, Y. (2014). Barns könade vardag. Om (o)jämställdhet i förskola, förskoleklass och skola [Children's gendered worlds. About (in)equality in preschool, preschool class and school]. Stockholm: Liber

Odenbring, Y., Johansson, T., \& Lunneblad, J. (2016). Blaming and framing the family: urban schools and school officials talk of neglecting parents. The Urban Review, 48(3), 484-498.

Odenbring, Y., Lunneblad, J. \& Hellman, A. (2017). I småstadens marginal. Berättelser om en skolas integrationsarbete i en socialt utsatt stadsdel [In the margins of a small town. Narratives about a school's work with inclusion in a socially disadvantaged area]. Paideia, 14, 51-60.

Odenbring, Y., Johansson, T. \& Lunneblad, J. (2018). "Det är svårt för skolan när det inte är uppenbara försummelser" - Elevhälsan, utsatta elever och social klass ["It's hard for schools when there isn't obvious neglect" - The student welfare team, vulnerable students and social class]. Educare, 2018:1, 2642.

Öhrn, E. (2012). Urban education and segregation: The responses from young people. European Educational Research Journal, 11(1), 45-57.

Rodgers, Y. V., \& Milewska, M. (2007). Food assistance through the school system. Journal of Children \& Poverty, 13(1), 75-95.

Roets, G., Cardoen, D., Bouverne-De Bie, M., \& Roose, R. (2015). We make the road by walking: challenging conceptualisations of leisure time for children in poverty. Children \& Society, 29, 277-287.

SFS. (2010). 800. Skollagen [education act]. Stockholm: Regeringskansliet.

Save the Children [Rädda Barnen]. (2002). Barns ekonomiska utsatthet under 1990-talet. Bidrag till ett kommunalt barnindex [Children's economic hardship during the 1990s. A contribution to a municipal children's index]. Stockholm: Rädda Barnen.

Save the Children [Rädda Barnen]. (2013). På marginalen. Vardagen bakom barnfattigdomsstatistiken [On the margin. Daily life behind child poverty statistics]. Stockholm: Rädda Barnen.

Save the Children [Rädda Barnen]. (2014). Barnfattigdom i Sverige [Child poverty in Sweden]. Stockholm: Save the Children.

Sernhede, O. (Ed.) (2011). Förorten, skolan och ungdomskulturen. Reproduktion av marginalitet och ungas informella lärande [The suburb, school and youth culture]. Göteborg: Daidalos.

Skeggs, B. (2002). Formations of class and gender. Becoming respectable. London: Sage.

Skeggs, B. (2004). Class, self, culture. London: Routledge.

Tuason, T., Marcetic, A., Roberts, S., Stuart, K., \& Rearick, J. (2009). The refuge: an after- school care programme for African-American children in poverty. Early Child Development and Care, 179(7), $977-$ 997.

UNICEF (2012). "Jag är bara 15 år, men ibland känns det redan som att det är kört." Ungas röster om social utanförskap i Sverige [I'm only 15 years old, but sometimes it feels pointless". Adolescents talk about social exclusion in Sweden. Stockholm]: Stockholm: UNICEF.

Wacquant, L. (2008): Urban outcasts: A comparative sociology of advanced marginality. Cambridge: Polity. 